Original Research Paper

\title{
Election in Malaysia and Indigenization of Democracy
}

\author{
${ }^{1}$ Kartini Aboo Talib @ Khalid, ${ }^{1}$ Shamsul A.B and ${ }^{2}$ Suraiya Ishak \\ ${ }^{1}$ Institute of Ethnic Studies, Universiti Kebangsaan Malaysia Bangi Selangor, Malaysia \\ ${ }^{2}$ Faculty of Social Sciences and Humanities, Universiti Kebangsaan Malaysia Bangi Selangor, Malaysia
}

\author{
Article history \\ Received: 11-06-2018 \\ Revised: $26-07-2018$ \\ Accepted: 17-08-2018 \\ Corresponding Author: \\ Kartini Aboo Talib@ Khalid \\ Institute of Ethnic Studies, \\ Universiti Kebangsaan \\ Malaysia Bangi Selangor, \\ Malaysia \\ Email:k_khalid@ukm.edu.my
}

\begin{abstract}
Election and democracy have coexisted but the Western interpretations of democracy though dominant, yet contestable. In a democracy, election serves as a tool to elect representatives. Election is held regularly to avoid power absolutism. However, democracy is conceived differently due to history, society and local contexts. In Malaysia, democracy and elections were introduced during the undemocratic colonial period in the absence of political parties, homogenous social structure and economic prosperity. This paper argues that the introduction of democracy during the colonial era left Malaysia with its unique form of democracy and the understanding of election. The findings conclude that the indigenization of democracy including the local context, colonial knowledge and inheritance, culture and norms resulted in projecting a different form of democracy. This study utilizes secondary data through process tracing of historical facts and contemporary realities to debate the issues.
\end{abstract}

Keywords: Election, Democracy, Indigenization, Alliance, Mediation

\section{Introduction}

This article examines the introduction of election in Malaysia and argues that it was introduced during the undemocratic colonial era. Therefore, the understanding of election and democracy was pre-mature to the new multiethnic society that was still under the colonial power, segregated and underdeveloped. Second, the introduction of election was of an attempt by the colonialist to test the level of readiness of the ethnically divided society. This introduction was coercive and it was also a prerequisite for independence. Finally, it argues that the indigenization of democracy has resulted in creating a different form of democracy away from the Western types of democracy. Hence, the application of democracy is varied and differed. The sub-themes that emerge in this article are variation of democracy, the setting of colonial knowledge that becomes the bread and butter for managing election, the application of power sharing and the utilization of bargaining, negotiation and mediation formula and underpinning issues such as vote buying and local norms that construct the way democracy is practiced in Malaysia.

\section{Democracy and Variations}

Although, the Greek words of demos and kratos refer to power that ruled by the people, the actual use of these words is beyond (Klein et al., 2011). The meaning of democracy as rule by the people, of the people and for the people; the demand is not rest just about the people, but it requires a well understood group of people with good attitudes, integrity, accountability to carry the duty. Managing people's behaviors means that absolute variation is inevitable. Lane et al. (2003) define democracy as a system of human institution for governing a country and the system is influenced by exogenous and endogenous factors such as economy, culture and institution. Economically, it refers to market contribution to democratic stability that adopts free competition to determine the supply, demand and need. In a cultural context, it allows basic human rights to play a role and to participate in facilitating democracy. At the institutional level, it means framing the institution to enhance democracy through good governance. But if the institution corrupts, then democracy is likely to wither.

Mainwaring and Perez-Linan (2012) and Klein et al. (2011) share the understanding of democracy that this definition possesses several features such as fair election to enable peaceful regime change, the principle of majority rule in decision making, the protection of freedom and liberty, the exercise of good governance, a state is not overshadowed by military power and a society committed to tolerance, cooperation and compromise. Nevertheless, the varieties of democracy show that it is a system that must be assessed according to place and contexts. There is no one size fits all 
condition when it comes to democracy. Tocqueville's views on democracy emphasize three factors in assessing the form of democracy in the United States of America such as geography, civil society and political institution. The spatially wide geo-physical and distance requires the USA to adopt decentralization to manage the federal-state relationship; the progressive civil society including nongovernmental and nonprofit organizations allows the American societies to coexist in harmony with the Constitution safeguarding their basic rights; and the separation of power in the institutions with check and balance practices encourage democracy to live well in the USA.

In addition, Kramnick and Bevan (2003) agrees that Tocqueville's assumption of democracy will perpetuate if civil societies and power decentralization in a spatially wide geo-physical will be coexisted in harmony. People's participation through civil societies will eventually demand for freedom to exist and human associations will urge people to work collectively to care for one another. Moreover, the decentralization system would allow power to be dispersed with check and balance approach applied to ensure institutional integrity.

Majoritarian democracy adopts a simple majority as the rule to derive a decision. It favors the rule of majority and the good example of the Westminster model. Meanwhile, Madisonian democracy based on James Madison in his gazette of Publius views that democracy must be married to constitutionalism and a veto power is necessary on the basis that such power will prevent the majority from suppressing the minority or one minority from suppressing the other minorities. On the contrary, constitutional democracy is the antithesis of arbitrary rule. The authority of the majority is limited by legal and constitutional means. As a result, the rights of individuals and minorities are respected. Such legal order contains rights and immunities that are absolute and it restraints the power of government to achieve the rule of law.

Elitist democracy based on Schumpeter's idea focuses on political parties and elites where democracy is in the hand of a few people that are elected by the people. Thus, such concentration of power in the hands of a few will not derail democracy because the competition among elites allows democracy to prevail (Sniderman et al., 2009). Populist democracy is based on Jean Jacques Rousseau's social contract (1762) that concisely highlights the 'general will' of the people that must be carried out with responsibility and accountability to deliver services to the people. Political decisions must be based on the publics' popular demand and the political elites must submit themselves to the people and work hard to fulfill the public's demand.

Diamond et al. (1989) argue that Dahl's term of polyarchy is referring to a system of government that meets three essential conditions including meaningful competitions among individuals and organized groups, inclusive political participation and political liberties that strengthen the integrity in political participation as well as competition. Hence, polyarchy form of plural democracy recognizes the participation and contribution of many people, institution and organizations to uphold democracy. This polyarchy model is in tandem with the consociational democracy. The latter provides a basis for explaining democracy in a plural divided societies like Malaysia.

In another aspect, the consociational democracy also challenges the above mentioned models of democracy from the majoritarian to elitist which are incapable to handle a decision making process in a plural divided societies especially a state that has strong ethnic profile and religious cleavages. The consociationalism emphasizes a grand coalition and power sharing to achieve political stability. Thus, Lijphart (1991) suggests federalism government, constitutional review, multiparty and bicameral parliament as essential elements for stability. However, there is no clear cut consensus among scholars in deciding which types of democracy is the best practice because all democracies are a mixture of consensus amongst people, parties and institutions. Furthermore, in democracy, certain groups will have more say than others and this condition may turn any form of democracy into a game played among elites.

The list of Western's democracy remain at the core in framing the debates on what democracy is and the elements fit for it. Representative democracy in many former colonies was an epochal transformation that will sustain the values of capitalism. One of the value is a free market competition in capitalism. This value promotes free market democracy and liberty that is contested as the tools for peace in managing multiethnic society. For instance, Chua (2004) opines that a free market democracy brings trouble to multiethnic societies when economic control is in the hand of the market-dominant minority. Since the free market system determines the supply-demand and those who has the gold rules, democracy becomes entangled in the order for freedom and liberty within Western's perspective because in a multiethnic society that is influenced by colonial history, an imbalanced societal context and power structure with minority group dominating the market at the expense of indigenous majority, this is a recipe for conflict.

Consequently, Malaysia consists of market dominant minority - the Chinese is controlling the economy while the majority Malays and Bumiputera are still struggling to improve their economic ownership. In addition, the unique practice of democracy gives Malaysia a few interesting names such as quasi-democracy (Zakaria, 1989), semi-democracy (Case, 1993), repressive and syncretic state of democracy (Jesudason, 1996). Therefore, the version of democracy seems to vary 
extensively through the region, history and practice. Referring to Dahl's polyarchy form of plural democracy, it demands a state to conform with three essential conditions such as competition among individuals and groups at regular interval without force, a high level of political participation in selecting leaders, policies, elections in all level of societies and finally, the level of liberty to civil and political parties including freedom of expression, press, etc. are to ensure the integrity of political competition and participation prevails; but such conditions are contestable relatively in Malaysia.

\section{The Setting: Colonial Knowledge and Inheritance}

Due to the British's policy that brought in the influx of immigrants from China and India in the 1930s to work at the colony's rubber plantation and tin mining, a plural society emerged in Malaya. The British segregated the migrants from the indigenous community. Furnivall $(1967 ; 2010)$ argues that a plural society comprises of two or more social orders, a striking racial make-up with little intermingling among communities, with interaction limited to trade and business and economic role was profiled based on ethnic groups. Consequently, the colonial economy operated in a way that placed the indigenous community inferior to the competitive migrants.

Shamsul's (2011) discourse on identity in Malaysia analytically outlined the contestation of the identity caused by the colony that continued to degrade society in many ways. He further argued that racial identity was categorized and shaped by the colonial history that simply reaffirmed colonial power for decades. A modern society of Malaysia allows this colonial knowledge to categorize the multiethnic society with little intervention is done to challenge it. For instance, the preservation of ethnic identity through colonial controlling and representing is embedded in the education system through vernacular schools. Furthermore, Fernando (2012) argued that it was the colonial policy that divide society in a way advantageous for them to manage the people and resources. Such division discouraged immigrants from China and India brought by the British to interact with locals in their daily activities and this further intensified their primordial sentiments. The only public space that these people connected was the public market, where interaction was limited to trading (Geertz, 1973).

Segregation and division of labor according to ethnic profile was significant to urbanization process. In urban areas, population density showed a concentration of Chinese community while in the rural areas were populated by the Malays and Bumiputera. Division of labor based on ethnic label showed significant numbers of employees who worked for the British as low income workers, uneducated, impoverished, lived in the plantations or mining areas guarded by the British. This condition was prominent before and after independent. As a result, the societal hierarchy and layers of disconnected relationships amongst migrants and locals do not fit in the description of middle class society as a prerequisite element for democracy.

Furthermore, another precondition of democracy is election and in Malaya, it was introduced by the colony before independence of 1957 . Democracy was introduced to the people through the idea of election as a democratic participation of the people. Election was brought by the British as a prerequisite for independence. It began with the introduction of ethnicbased political parties that originally they were community based organizations. For example, United Malays National Organization (UMNO) was a collection of association of twenty nine various clubs including lawyers, entrepreneurs, teachers and journalists. While, the Malay Chinese Association (MCA) was a lottery and funeral association handling the Chinese's interests. Later these community based organizations turned into political parties because they were organizations representing different ethnic groups, reachable and recognized by the British to compete in local council and municipal elections in the early $1950 \mathrm{~s}$.

Moreover, the first general election before independent was held in 1955 and this election was held as a preparation for independence. British was evaluating whether or not the Malaya people were ready for independence. In this general election, these organizations formed a political coalition known as the alliance. Nevertheless, the formed of coalition model could be traced back to the formation of the Communities Liaison Committee (CLC) in 1949 by the British to foster a closer relationship between the elites of different ethnic groups especially in constructing a political compromise agreed to by all ethnic communities (Fernando, 2012). The built up to as well as the results of the first general election in 1955 was the first attempt by locals at self-rule. Consistent election every five years is routine in Malaysia, but to see the same party such as Barisan Nasional (BN) the alliance of major political parties representing power sharing amongst the ethnic elites to lead the nation for more than fifty years leaves a question to be unraveled.

\section{Power Sharing: The Bargaining, Negotiation and Mediation Formula}

The Malaysian Constitution had a long gestation period, right from the time the British established the Federated Malay States (FMS) in July 1896, which brought together four states in an administrative entity which had no historical antecedents. To enable this 
centralized administrative unit to operate fully they had to create a standardized rule of law and administration whilst it was yet to be referred to as a formal constitution. When the Federation of Malaya Agreement of 1948 was signed it signaled the beginning of the direct shaping of a Malaysian Constitution by the Reid Commission which was initiated in 1955, after the first ever nationwide general election. This resulted in the promulgation of the Merdeka Constitution of 1957. Then came the Federation of Malaysia Constitution of 1963. Throughout the formulation of each of the constitutions there was always a process of prolonged negotiation among the difference parties. As a result, the Constitution in Malaysia is always seen as a 'social contract' because it came about as a result of some form of agreement as to what to agree and to disagree between the different ethnic representatives and interest groups.

The racial identity as defined by the colonial knowledge and intention farther sharpened the gap among the races as assurance for the British to remain influential. British brought a system that was believed to be able to rule the nation in a way British wanted and was familiar with. The idea of election was institutionalized in Malaya as pre-requisite for independence. Fernando (2012: 282283) argues that after Malayan Union (MU) was abandoned following massive protests, the 1948 Federation of Malaya Agreement was designed to replace it. The All Malaya Council of Joint Action (AMCJA) however responded with disconsolate reaction and held demonstrations to protest the lack of consultation with the non-Malay communities in the negotiation for constitutional changes. The dissatisfaction continued and the Japanese occupation further challenged intercommunal relations. The immediate post war approach to reduce the racial tension introduced by senior British Administrators particularly the Commissioner General for Southeast Asia, Malcolm MacDonald was to hold confidential discussions to resolve outstanding issues congenially and to reduce the tension among the multiethnic communities.

Again, the establishment of CLC was a potent attempt by the British to promote inter-elite cooperation that resulted in multiracial political alliance in Malayan politics (Fernando, 2012). The deliberations of CLC was a means to achieve national consensus and national building. Although CLC was an informal body, many agreements reached at CLC meetings were adopted by the government. Furthermore, CLC's records indicated that the body also served as a useful platform for the colonial administration as a trial platform to test new ideas and potential policies (Khalid, 2014). On a broader dimension, the CLC created a pragmatic framework for political elites to hold inter-ethnic bargaining and negotiation in private that influenced the emergence of consociation politics in Malaysia.
The attraction of power sharing is necessary to create an avenue for competing groups to work together and perhaps to be able to avoid hostility. In fact, sharing limited resources works best in a plural context allowing each competing entity to acknowledge the need to work collectively. In this discussion on the power sharing models, most models promote coalition or alliance as the means to achieve the said objective. Practicing high tolerance, taking into account the majority and minority views and votes and finding a common ground as much as possible would ensure a reciprocal understanding and acceptable decisions. Moreover, these models cannot work successfully without improvising some conditions to the circumstances, either accommodating the current demands or eliminating the unnecessary ones. Ironically, both conditions trigger the very basic questions of what, why, how and who would benefit from any decision. These conditions could also lead to misperceptions of power sharing models such as elite groups or the dominant majority faring better than nonelites and minorities.

Other models to be considered when discussing multiple competing groups is the coalition bargaining model besides the consociation model by Lijphart (1969; $1977 ; 1991)$ that is a common referred model in discussing Malaysia. This model is a dynamic bargaining model applied to coalition formation. Diermeier et al. (2008: 485) argues that equilibrium could be maintained in this coalition through negotiation. The negotiation allows members to voice their proposals and if negotiation fails, there are chances for coalition members to extract favourable agreement from their counterparts and let the process continues. This majority bargaining process also means that it is not necessary to reach consensus among all negotiating parties to come to an agreement. Decision can be made based on majority votes. However, being excluded from the coalition formation would create a disadvantaged position to the minority group especially when the other groups manage to support other and conspire to reject the uncooperative group. Furthermore, Eraslan and Merlo (2002) argue that the fear of being excluded from future proposals and processes of coalition formation leads to an ineffective decision because such fear would predispose parties in the coalition to make a quick decision on a certain matters.

Holyoke (2009: 360) argues that competing interest groups can from a coalition if pressure from thee legislators and competitor groups is high. Furthermore, he argues that competition among interest groups can become more combative when a potential policy outcome is perceived to bring harm to member of the interest groups. Thus, interest groups may need to reconsider their objectives and find the best way to achieve their goals, even if it entails working together with their competitors. When competing interest groups 
recognise their power limitation and resource scarcity, rather than fight with their competitors, they may be willing to pool their strengths and agree to form a coalition that advocates their cause. This argument is

Coalition in a majority system offers ways to win people's votes. Bargsted and Kedar (2009) clarify that in a majority system, voters' preferences are subjective but they are likely to incorporate chances for victory when choosing a candidate or political party, either individually or as part of a coalition, before casting their ballots. Strategically voters are likely to support a candidate from a coalition party that provides a strong national-unity ideology. Different political parties that form a coalition demonstrate positive credibility when they can overcome competing differences and interests and are able to convince voters that a common national agenda can be established for the wellbeing of all citizens. Another facet of party behaviour is that parties do not represent their voters' perspectives directly, but they are likely to adopt relative extremism or relative moderation in order to maximise votes in an election or to influence coalition outcomes (Warwick, 2009).

Furthermore, Bargsted and Kedar (2009) anticipate that the moderate or extreme positions will involve compromise across party positions. In a left or right wing party, members will eventually move their position of decision making or agenda manoeuvring closer to their polar preference (Warwick, 2009: 277). Here, bargaining is at play and having a coalition-based system may create cross-pressures for serving party supporters. On one hand, political parties have electoral clienteles that expect to see their ideological stances reflect the party's political pursuit. On the other hand, party supporters would like to see those stances translated into a policy that promises to benefit them.

Stevenson et al. (1985) discuss a concept of coalition that is diverse and applies to different contexts. The management context focuses coalition within an organisation that is composed of employees, managers and stockholders over issues including conflict over budget, allocation of functions and precedent. Additional bargaining issues include decision making processes, problem solving mechanisms, goal setting competitions and allocating scarce resources. The aggregate of problems varies depending on a crisis or a non-crisis condition. The leverage for bargaining is higher in a noncrisis than a crisis condition because the latter would restrict each group to bargain over each preference when resources are limited and crisis resolution is at stake. Stevenson et al. (1985) and Mintzberg (1983: 259) argue that a political analysis model of coalition is translated into organisational policy and action within the framework of legislative coalition in order to maximise policy outcome for members. Thus a coalition is formed to maximise this advantage because people or parties are self-interested. If they support similar ideologies, forming a coalition would enhance their chances of winning on proposals, decisions, or votes.

Drawing from the above discussed models of coalition, Malaysia is a multi-racial society and great tolerance among races to achieve a harmonious balance is required. Common interests and goals are difficult to achieve when each race has competing interest with which to deal. Even with inter and intra-race relationships, competing interests could disintegrate into factions that disrupt this delicate balance. The intraracial factions within an ethnic group could spark conflict that turns into a complex condition where a portion of the ethnic group abandons its progeny and becomes aligned with another ethnic group. PKR and DAP are the common examples of a minority ethnic group will join a party with a dominant Chinese or Malays due to the party's open policy. In another occasion, the Malays still maintain their beliefs and values despite differing political ideologies among Malays political parties such as United Malays National Organization (UMNO) and Parti Islam Se-Malaya (PAS) and Parti Keadilan Rakyat (PKR). Similar conditions exist with the Chinese communities between MCA (Malayan Chinese Association) and Democratic Action Party (DAP). MCA decided to join BN, a political alliance comprises of UMNO, MIC and etc. instead of joining DAP (Chinese dominated party). The alliance among multi-ethnic political parties, although each representing different ethnic interest, the quest for power sharing in Malaysia is still the only formula for the alliance to win the election.

The ethnic divisions in the population census of 2016 ${ }^{\mathrm{i}}$ provide a reflection that political parties that form the alliance need votes from other ethnic groups in order to win the election. This is because the intra-ethnic factions within the Malays, Chinese and Indians may deconstruct the understanding of victory in the election. A political party can never win an election just from the Malays' voters alone. In addition, having competing interests with resource scarcity in a small country like Malaysia, could be a blessing in disguise because each ethnic group needs to depend on another for resources, skills and capital - the Ali-Baba business partnership when the Malays who get the government contract lease it to the Chinese or Indian for the skills and capital, thus allowing the business to function. The same coalition and support is applied to political parties in Malaysia.

In addition to power sharing, the rural Malays struggle with their peasant-level economic limitations, while the urban Malays complain over limited business opportunities and the lack of incentive to cope with the increasing cost of living. The Chinese that populate most urban areas now demand equality despite their economic good fortune. Some of the minority Indians still live in 
hardship on rural plantations while others manage to climb to higher income brackets and social positions. The issue of poverty and underachievement amongst minority Indians has prompted NGOs and the government to provide a policy of social inclusivity in helping this minority group (Jayasooria and Nathan, 2016). Proportionately the Malays are still the majority in public civil services, whilst the Chinese control the private sector and the Indians make up the remaining positions in both public and private sectors. The natives in Sabah and Sarawak are engaging significantly at the local and federal levels, despite compelling issues on inclusive development, state autonomy and federal-state power relations. Here complementary interactions, mediation and relationships allow each ethnic group to support one another. Reasons for harmonious coexistence include tolerance at the workplace, cooperation and peacekeeping within neighbourhoods and public schools and the growing number of inter-ethnic marriages. All of these factors contribute to improve the social cohesion ${ }^{\mathrm{ii}}$ in the multi-ethnic society as well as retaining the need for power sharing.

In sixty-one years of Malaysian independence, the only tragic incident that reflected poor race relations was way back in 1969 . The tragedy was due to many factors including unequal economic opportunities across ethnic groups (Jomo, 1986), poverty issues and imbalanced urban-rural development. However, the revisionist view like Soong (2007) argues that the race riot of 1969 was a de facto political coup against the Tunku Abdul Rahman's administration - the First Prime Minister of Malaysia. Johan (2016:111) argues that the failure of the alliance model of mediating communalism was to be blamed for the outbreak. Thus, the establishment of the New Economic Policy (NEP) was politically engineered to enable the Malays to improve their economic status and to ensure their dominance in electoral politics. The government took a major role to restructure every issue related to race disintegration through national programs other than NEP including the national principles of Rukunegara, vision 2020 and the national cultural policy (Zahid, 1997; Zainuddin et al., 2005). It is now evident that for a multiracial state to contend with varying interests, differences and diversity, the government must play a leading role in ensuring that the mission of unity is realised. The moderation approach through mediation amongst different ethnic groups emerges as a reliable method in managing tensions and maintaining harmonious relations among them.

Moderation through bargaining and negotiation has created a strong foundation among the multiethnic society in Malaysia to consider election as an avenue for political change. The Electoral Commission is responsible for managing the election process in Malaysia based on Article 19 of the Election Act of
1958. This agency is supposed to be independent and nonpartisan in its dealing with political parties. Members are appointed by the King, Yang DiPertuan Agong subject to prior discussion with the Majlis Raja-Raja (the Council of Rulers) composed of all nine Sultans. In general, the rules and regulations provided for in this agency must be approved by the King and presented to the House of Representatives for amendment or nullification of rules. However, the Electoral Commission has frequently been accused of being partisan to $\mathrm{BN}$ as the government of the day. For instance, there was a reform to the electoral system in 2000 (the $10^{\text {th }}$ election) where gerrymandering was implemented to reconstruct the district lines. However, the new districts were identified and districts voting pro-government were given more seats in parliament than districts that were strong supporters of opposition parties. Thus, gerrymandering has been criticized for being discriminatory through invalidation on the grounds of population equality. This agency's integrity was questioned through a series of civil protest known as Bersih 1 to 4 . These protests were organized by NGOs and opposition political parties, but the movement lost its momentum when it did not result in any significant regime change (Sulaiman and Khalid, 2017).

\section{Election and Vote Buying}

The instances of election and vote buying provided in this segment discuss the process and outcome of election in a few countries in Southeast Asia. Most of them are former colonies of British, Dutch, French and Spanish. Election may be a fundamental element in democracy, but the local contexts may deconstruct the actual meaning of election into undemocratic practice to maintain status quo and power.

Elections are held to ensure power is not monopolized by any single group. Therefore, competitive struggle amongst political parties' will help the democratic system prevail and do better. The vote system is to elect a government and it is implemented periodically and regularly to avoid power absolutism. In addition, the voters' role is not to decide on political issues but to choose representatives who will carry out those decisions (Kurki, 2014). However, election does not guarantee greater amount of individual freedom because what defines freedom is pretty much related to the government in power and the constitution. In fact, election is about competition for leadership and political parties do not always stand for ideological values but are merely groups of individuals who come together to win power and gain leadership. Thus, election can exist in a socialist, capitalist, or even in a religious traditionalist states. 
The challenge of carrying out transparent elections is common in many countries. One such challenge is vote buying. Parenti (2010) contends that vote buying involves the exchange of money, goods and services for votes including soap, tires, chairs, sarong, watches, chickens, singles, cement, whisky, coffins, haircuts, cigarettes, fertilizer, bicycles, funerals, vasectomies, dictionaries, fumigators, Viagra, oxycontin, television sets, free rent, rugby balls, dried meat, mobile phones, birthday cakes, electric fans, cooking oil, bags of rice, barbed wire, corn grinders, plastic sheeting, washing machines, plastic surgery, teeth cleaning, etc. Such offers occur before the election and during the campaign by political parties. The effort to win the heart and mind of voters becomes unethically costly. Though vote buying was considered a phenomenon of olden times in backward places and it is making an impressive comeback. For example, Parenti (2010) discusses that vote buying was common in ancient Rome especially during the late republic, where it was called "ambitus" (from the word ambire, go around or canvass support). In England as far back as in 1660 s, candidates treated voters to food and drink. At the birth of US democracy, before the Declaration of Independence, voters were treated with intoxicating drinks. Such practice was conducted by George Washington in his first race for the Virginia House of Burgesses in 1758. He bought 160 gallons of rum, wine, beer and cider to treat 391 voters and their hangers-on. Today, vote buying is a worldwide phenomenon. Reports of vote buying are multiplying as more and more democratic countries introduce competitive elections. In fact, the amount of money offered to voters varies depending on the competitiveness of the election and level either local or general. The candidates themselves can be a factor.

Parenti (2010) outlines cases of vote buying across regions and highlights that the amount of money distributed also varies according to the country. In Manila voters received 30 pesos (US 60 cents) in noncompetitive local race in 2002, in Kuwait 1996 parliamentary election reports noted voters' received more than 3,000 dinar (US10k). In Thailand in the 1996 general election the average offer was 678 bath (US27) and there were spatial differences with urban dwellers in Bangkok were likely to receive more than rural residents; Gypsies in the Greek City of Sofades received about US16 per vote; in Russia voters were offered 50-100 rubles for their votes in the 2000 election; in Mexico, voters received 250-500 pesos (US25-50) per vote; in Thailand vote buyers made lavish donation at weddings and at the high end of vote buying, a congressional candidate in Southern Luzon in the Philippines admitted to doling out 4 million pesos (US160K) on the eve of 1992 election, in Brasil candidate running for the state assemblies handed out up to US1million each, in Taiwan typical legislative candidates in urban areas easily distribute up to NT\$100 million (US3million).

Based on the Perceptions of Electoral Integrity (PEI) global surveys of 127 national parliamentary and presidential contests held from 1 July 2012 to 31 December 2014 in 104 countries worldwide, Southeast Asia performed the worst on overall electoral integrity in the world. ${ }^{\text {iii }}$ The average PEI Index for Southeast Asia was 56 out of 100 compared to the global average of 64 , which means the region ranks below Western and Central Africa and the Middle East [other places rife with flawed or failed elections]. The indicators identified to measure electoral integrity include electoral laws, electoral procedures, district boundaries, voter registration, party/candidate registration, media coverage, political finance, voting process, vote count, election results and electoral authorities. Singapore, Malaysia and Cambodia are some more hegemonic with varying degree of contestation in their election process. The Philippines has a history of more than 100 years of elections, while Myanmar is just emerging from decades of dictatorship, Indonesia and Timor Leste seem to be on a remarkable reform towards liberal democracy. Thailand, has slid back into dictatorship with a coup détat and military intervention. Finally, Brunei does not hold any representative national election to the legislature at all [Brunei is an absolute monarchy].

The Philippines (PL) is rated as moderate in most categories of electoral integrity yet issues related to political finance (PL 36; Global average 51) and the voting process (PL53: Global average 66) are exceptionally problematic. In the 2013 elections, Camboodia showed voter registration score of 30 compared to the global average of 62 and the aggregation and announcement of results score (Cambodia 40; global average 72) were flagged as exceptionally poor. Thailand presents a unique case, its election was derailed due to the violent disruption campaign of the opposition People Democratic Reform Committee and the subsequent disenfranchisement of millions of voters. The 2014 election deepened Thailand political crisis, especially when the constitutional court annulled the contest on 21 March 2014 and the military staged a coup dé tat on 22 May 2014, the second coup in a decade. International watchdog organization registered a significant deterioration of the human rights situation in Thailand since the coup. While, Indonesia (INA) is criticized on the political finance (INA 47; Global average 51); the issue of money politics is reflected in its vote buying in over $30 \%$ of observed polling places in 25 provinces and vote brokers with changing loyalties remain instrumental for all political parties to get out the vote.

Myanmar had its election on November 2015. Since 2010, the country has undergone massive economic 
liberalization with a transition from a closed military dictatorship to a formally electoral political system. The 2015 polls are seen as the test for the newly built institutions. However, the persistence of military power and state-facilitated crony capitalism are viewed as the deterrence factors for the reform process. Various constitutional provisions such as the allocation of $25 \%$ of seats in the legislature reserved for the military, continued fighting in Kachin and northern Shan states and violation of human rights against Rohingya in Rakhine decrease the integrity of the polls. In Vietnam and Lao PDR elections were last held in 2011 and in both countries elections are often dismissed as mere charades as they are the one-party states.

Finally, for Malaysia (MY) the result of PEI was evaluated worst on electoral laws, especially to the May 2013 general election (MY 33; Global average 64) and on the delimitation of voting district boundaries (MY 28; Global average 64). The score for district boundaries was, in fact, the lowest in the world - followed closely by the US with the second lowest score. The ruling Barisan Nasional (BN) won only $46.5 \%$ of the vote but gained 133 or $59.9 \%$ of seats in the House of Representatives). Critics refer to this phenomenon as an attributed to the mal-apportionment of voting districts and other irregularities. Rural constituencies that remain strongholds of the ruling party create strong advantage to BN compared to the urban areas. The Bersih movements and other electoral reform campaigners organized large scale protests in response. Electoral reform has stalled due to the stark polarization of the electorate.

\section{The Indigenization of Democracy}

Fukuyama (2014) compares a few unrest scenarios within the scope of demand for democracy, indulged democracy and the progressing democracies referring to Arab Springs, the US complex financial crisis, the protests in Turkey and Brazil which both countries are the emerging market economies with competitive elections as the element of practicing democracies but convulsed with mass protests against their government. He further argues that a connection exists between prosperity and democracy, but he does not agree that one leads automatically to the other. He argues that a successful liberal democracy requires a combination of three essential elements such as the state, rule of law and accountability. The central authorities must be able to exercise check and balance to ensure that the system is transparent. Balance among these elements is crucial, but too many checks and balances will paralyze the system. Fukuyama contends that the timing factor is also important.

Keane (2011) listed the prerequisites of democracy such as: A sovereign state, political parties and competitive election, homogenous social infrastructure and steady economy and wealth. But since these were absent in the case of India, Taiwan, South Africa, Botswana, Nepal and Tibet. It provided the reason for the failure of democracy. He further argues that lack of scrutiny of powerful organizations lead to the deterioration of the quality of democracy. In this $21^{\text {st }}$ century, the classical perspective and idealism of democracy has been challenged by the corrupted system of democracy.

Comparative studies of democracy in different regions continues to dominate the discourse. Many contemporary aspects of democracy are applied to assess democracy. Although contemporary factors are interesting, the past that created the present should be taken into account too in assessing the variations of democracy. Indigenization factors such as history, society and local contexts create variations in the understanding of power and democracy. In fact, democracy and election were introduced to Malaya during the undemocratic colonial period in the absence of political parties, homogenous social infrastructure and little prosperity.

First, the history of feudalism cultivated the norms and culture of patronage in the society. Later, the imperialists came and coercively changed the local system to meet their mercantile and demands for resources, labor and markets. Moreover, as the society and the world evolved, the quest and struggle for independence simply spread the colonial knowledge in a new form of power transfer that ensured continuous support will be given to the colony after the independence. As a result, in the Malaya context, the CLC was a prerequisite from the British for the multiethnic Malayans to show their willingness to cooperate among them for the sake of independence. This epochal transformation without much ado helped to ensure that the British remained a strong ally and reference to independent Malaya.

Second, the establishment of political parties was the result of protest against the introduction of the Malayan Union by the British in 1946. For instance, the United Malay National Organization (UMNO) was a community based organization made up of twenty nine diverse Malays associations from different Malay states that championed the protest against the provision enshrined in the Malayan Union. While, the Malay Chinese Association (MCA) was previously a lottery and funeral club together with the Malay Indian Congress (MIC) which were founded in the wake of Malayan Union where MCA and MIC joined the All Malaya Council of Joint Action (AMCJA) seeking for inclusive participation of non-Malays in preparing the Federated Malaya Agreement of 1948. Thus, these political parties were formed as a reaction to protest the British. Many of these ethnic-based associations looked after the welfare of each ethnic group. The idea of democracy and election had not taken root and 
the establishment of political parties was a response to British's precondition for independence.

Third, in addition to the absence of political parties, a homogenous social infrastructure such as a national identity with a common language, customs and shared history were unknown to the people of Malaya. Shamsul (2015) argues that colonial knowledge and nation of intents provide a significant perspective to consider Malaya a state without nation ${ }^{\text {iv }}$. National identity was construed by the British through ethnic categorization that later complicated the efforts at nation building. To date, Malaysia is a state without a nation but it possesses a strong social cohesion to explain the relatively peaceful and harmonious condition that the country relatively enjoys. Unity in diversity describes Malaysia with its vernacular school system, multi-religion and multiethnic. Thus, Keane (2011) arguments on the prerequisite of homogenous social infrastructure for democracy has been nullified in assessing Malaysian society during the colonial and post-colonial period.

Finally, economic well-being and wealth distribution during the colonial and post-colonial era shows significant differences and achievement. However, the basic idea of having positive discrimination (Harding, 1996) in describing the distribution of wealth and resources to the society is still existed in Malaysia. Hence, pocket of poverty is persistent throughout the states like Perlis, Kedah, Kelantan, Terengganu and Sabah and Sarawak - a wide population of Malays and Bumiputera. Furthermore, inclusivity in development and urbanization are comparatively poor in east coast Malaysia (Jayasooria, 2016). In fact, $90 \%$ of the economy is still dominated by the minority Chinese (Chua, 2004) though the issue of 30\% Bumiputera ownership and Malay supremacy is continuously highlighted by scholars (Johan, 2016; Kheng, 2002; Gomez and Jomo, 1997; Jomo, 1986). As a result, democracy is a contestable system in a multiethnic society because disparity in economic distribution results in layers of social class that could hinder the literacy towards political psephology.

The issues of vote buying, phantom voters, gerrymandering, abuse of government facilities and manpower and money politics are the results of the prematured process of democracy that has infiltrated into the system and society. The system becomes systemic when every democratic tool is controlled and monitored consistently by the regime. This was a reality during the BN government with constant hegemonic approach of carrot and stick - improving the wellbeing of the people simultaneously propagating the good image despite the corruption. Election became periodical and a regular festive to be celebrated every five years to show that democracy was in practice despite being criticized undemocratic by Weiss (2005) and Lemiere (2014). This explain the reasons why BN was able to dominate the election since independence until the fourteen general election of $2018 .^{\mathrm{v}}$

\section{Conclusion}

Democracy is a complex system that has been indigenized and improvised to meet the needs and interests of specific groups. Election was introduced in Malaya in the absence of all the democratic tools and elements. Democracy was introduced undemocratically for the sake of colony in the form of influence, network and patronage. Gradually, the post-independence era showed that the system becomes systemic over the years due to consistent control by the dominant regime through power sharing and the formed of alliance. Although the results of the recent general election of 2018 resulted in the new alliance replacing the $\mathrm{BN}$ with Pakatan Harapan (PH), most of the leader in $\mathrm{PH}$ are the former BN members, especially Tun Mahathir who had his 22 years of regimentation in the form of control which might continue in this new Malaysia for the quest of power. Although the progress towards good governance and clean elections continue to hover the debates on election and democracy, indigenization has redefined the common Western understanding of democracy into its own accommodative form.

\section{Acknowledgement}

Authors would like to acknowledge research grants AP2017-001/1 and GGP-2017-008 for funding this research.

\section{Funding Information}

Research grants AP-2017-001/1 and GGP-2017-008.

\section{Author's Contributions}

Authors have contributed collectively in preparing, developing and publishing this manuscript.

\section{Ethics}

Authors confirm that no ethical issues will arise after the publication of this manuscript.

\section{References}

Bargsted, M.A. and O. Kedar, 2009. Coalition targeted duvergerian voting: How Expectations affect voters choice under proportional representation. Am. J. Political Sci., 53: 307-323.

DOI: $10.1111 / \mathrm{j} .1540-5907.2009 .00372 . \mathrm{x}$

Case, W., 1993. Semi democracy in Malaysia: Withstanding the pressure for regime change. Pacific Affairs, 66: 183-205. DOI: $10.2307 / 2759366$ 
Chua, A., 2004. World on Fire: How Exporting Free Market Democracy Breeds Ethnic Hatred and Global Instability. 1st Edn., Arrow Book, London, ISBN-10: 1400076374, pp: 368.

Diamond, L.J., J.J. Linz, S.M.L. Boulder and L. Rienner, 1989. Democracy in Developing Countries: Asia. 1st Edn., Adamantine Press Limited, London, ISBN-10: 0744900093, pp: 489.

Diermeier, D., R.I. Swabb, V.H. Medvec and M.C. Kern, 2008. The micro-dynamics of coalition formation. Political Res. Q., 61: 484-501. DOI: $10.1177 / 1065912908316981$

Eraslan, H. and A. Merlo, 2002. Majority rule in a stochastic model of bargaining. J. Economic Theory, 10: 31-48. DOI: 10.1006/jeth.2001.2811

Fernando, J.M., 2012. Elite intercommunal bargaining and conflict resolution: The role of the communities liaison committee in Malaya, 1949-51. J. Southeast Asian Stud., 43: 280-301. DOI: $10.1017 / \mathrm{S} 0022463412000069$

Fukuyama, F., 2014. Political Order and Political Decay: From the Industrial Revolution to the Globalization of Democracy. 1st Edn., Farrar, Strauss and Girous, New York, pp: 3268.

Furnivall, J.S. 2010. Netherlands India: A Study of Plural Economy. 1st Edn., Cambridge University Press, UK, ISBN-13: 9781108011273, pp: 532.

Furnivall, J.S., 1967. Netherlands India: A Study of Plural Economy. 1st Edn., Cambridge University Press, UK,

Geertz, C., 1973. The Interpretation of Cultures. 1st Edn., Basic Books, New York.

Gomez, E.T. and K.S. Jomo, 1997. Malaysia's Political Economy: Politics, Patronage and Profits. 1st Edn., Cambridge University, United Kingdom, ISBN-10: 0521599962, pp: 228.

Harding, A., 1996. Law, Government and the Constitution in Malaysia. 1st Edn., Malaysian Law Journal Sdn Bhd., Kuala Lumpur, ISBN-10: 9679620379, pp: 315.

Holyoke, T.T., 2009. Interest group competition and coalition formation. Am. J. Political Sci., 53: 360-375. DOI: $10.1111 / \mathrm{j} .1540-5907.2009 .00375 . x$

Jayasooria, D. and K.S. Nathan, 2016. Contemporary Malaysian Indians: History, Issues, Challenges and Prospects. 1st Edn., Institute of Ethnic Studies (KITA), Bangi, ISBN-13: 978-976-0741-20-8, pp: 640.

Jayasooria, D., 2016. Inclusive development for urban poor and bottom $40 \%$ communities in Malaysia. UKM Ethnic Studies Paper Series, No.49.

Jesudason, J., 1996. The Syncretic State and the Structuring of Opposition Politics in Malaysia. In: Political Oppositions in Industrializing Asia, Rodan, G. (Ed.), Routledge, London, pp: 128-160.
Johan, S., 2016. Power Sharing in A Divided Nation: Mediated Communalism and New POLITICS in Six Decades of Malaysia's Election. 1st Edn., ISEAS, Singapore, ISBN-10: 9814695432, pp: 368.

Jomo, K.S. 1986. A Question of Class: Capital, the State and Uneven Development in Malaya. 1st Edn., Oxford University Press, Singapore, pp: 360.

Kurki, M., 2014. Politico-economic models of democracy in democracy promotion. Int. Studies Perspectives, 15: 121-141. DOI: $10.1111 / \mathrm{j} .1528-3585.2012 .00512 . \mathrm{x}$

Khalid, K.A.T., 2014. Moderation and power sharing in Malaysia: Accommodating concept and practice. Ethnic Studies Paper Series. No. 33. KITA, UKM. Bangi.

Kheng, C.B., 2002. Malaysia: The Making of a Nation. 1st Edn., ISEAS, Singapore, ISBN-10: 9812301542 , pp: 264.

Keane, J., 2011. Democracy in the Twenty-First Century: Global Questions. In: Globality, Democracy and Civil Society. Routledge, Carver, Terrell and J. Bartelson (Eds.). New York, ISBN978-0-415-54857-1

Klein, A., Y. Kiranda and R. Bafaki, 2011. Concepts and Principles of Democratic Governance and Accountability. 1st Edn., Konrad-AdenauerStiftung, Uganda.

Kramnick, I. and G. Bevan, 2003. Alexis de tocqueville: Democracy in america and two essays on America. Penguin Classic: New York, ISBN-10: 978-0140447606

Lane, J.E., S. Ersson and S.O. Ersson, 2003. Democracy: A Comparative Approach. 1st Edn., Routledge, London, ISBN-10: 0415265886, pp: 306.

Lemiere, S., 2014. Misplaced Democracy: Malaysian Politics and People. 1st Edn., SIRD, Kuala Lumpur, ISBN-10: 9670630177, pp: 349.

Lijphart, A., 1969. Consociational democracy. World Polit., 21: 207-225.

Lijphart, A., 1977. Democracy in Plural Societies. 1st Edn., Yale University Press, New Haven, CT, ISBN-10: 0300024940, pp: 248.

Lijphart, A., 1991. Power Sharing Approach. In: Conflict and Peacemaking in Multi Ethnic Societies, Montville, J. (Ed.). Lexington, New York, p: 491-510.

Mainwaring, S. and A. Perez-Linan, 2012. Democratic breakdown and survival in Latin America, 19452005. Proceedings of the Guillermo O'Donnell and the Study of Democracy, Mar. 26-27, Buenos Aires, pp: 1-42.

Mintzberg, H., 1983. Power in and Around Organizations. 1st Edn., Prentice Hall, Englewood Cliffs, New Jersey, ISBN-10: 0136868576, pp: 700.

Parenti, M., 2010. Democracy for the Few, 9th Edn., Wadsworth, Cengage Learning, Boston, USA. ISBN-10: 978-0495911265 
Shamsul, A.B., 2015. Politics of Language and Language of Politics: Theory and Practice of the Nation of Intent as articulated in Malaysia. 1st Edn., Institut Kajian Etnik, Bangi, Selangor, ISBN-10: 9670741106, pp: 26.

Shamsul, AB., 2011. Culture and governance in Malaysia's survival as a nation. Ethnic Studies Paper Series, No. 2. KITA, UKM, Malaysia.

Sniderman, P.M., J.F. Fletcher, P.H. Russell, P.E. Tetlock and B.J. Gaines, 2009. The fallacy of democratic elitism: Elite competition and commitment to civil liberties. British J. Political Sci., 21: 349-370. DOI: $10.1017 / \mathrm{S} 0007123400006190$

Soong, K.K., 2007. May 13: Declassified Documents on the Malaysian Riots of 1969. 1st Edn., Suaram Komunikasi, Kuala Lumpur, ISBN-10: 9834136765 , pp: 151 .

Stevenson, W.B., J.L. Pierce and L.W. Porter, 1985. The concept of coalition in organization theory and research. Acad. Manage. Rev., 10: 256-268. DOI: $10.5465 / A M R .1985 .4278178$

Sulaiman, N. and K.A.T. Khalid, 2017. Will there be Malaysia spring? A comparative assessment on social movements. Malaysian J. Commun., 33: 43-58. DOI: 10.17576/JKMJC-2017-3301-04

Warwick, P.V., 2009. Relative extremism and relative moderation: Strategic party positioning in democratic systems. Political Res. Q., 62: 276-288. DOI: $10.1177 / 1065912908320663$

Weiss, M.L., 2005. Protest and Possibilities: Civil Society and Coalitions for Political Change in Malaysia (Contemporary Issues in Asia and the Pacific). 1st Edn., Stanford University Press, USA, ISBN-10: 0804752958, pp: 344.

Zahid, E., 1997. Rukun Negara (The National Principles). In: Kenegaraan Malaysia, Abu Sabah, A.K. and J.A. Jawan (Eds.), UPM Serdang, pp: 201-209.

Zainuddin, R., M.M. Ismail and Z. Othman, 2005. Idealogi dan dasar Negara. Oxford Fajar Sdn. Bhd., Kuala Lumpur.

Zakaria, A., 1989. Malaysia: Quasi Democracy in a Divided Society. In: Democracy in Developing Countries Asia, Diamond, L., J. Linz and S. Lipset (Eds.), Lynne Rienner, Boulder, Colorado, pp: 347-381.

\section{Notes}

\footnotetext{
${ }^{\mathrm{i}}$ In 2016, total population of Malaysia was estimated at 31.7 million persons, an increase of 0.5 million as compared to 31.2 million in 2015 with 1.5 per cent population growth rate for the same period. Among Malaysian citizens, ethnic Bumiputera recorded the highest percentage with 68.6 per cent, followed by Chinese $(23.4 \%)$, Indians $(7.0 \%)$ and Others $(1.0 \%)$. The percentage of non-Malaysian citizen in 2016 was at 10.3 per
}

cent out of total population in Malaysia. https://www.dosm.gov.my/v1/index.php?r=column/cthemeByC at $\&$ cat $=155 \&$ bul_id $=$ OWlxdEVoYlJCS0hUZzJyRUcvZEYxZz 09\&menu_id=L0pheU43NWJwRWVSZklWdzQ4TlhUUT09

\begin{abstract}
ii Social cohesion is a term used by Shamsul AB (2011) to explain the multidimensional ethnic relationship in Malaysia. Unity is still a dream that has not yet been achieved but Malaysians enjoy relatively progress and peace due to the capacity of each race and institution to bargain and negotiate. Such bargaining and negotiation allows the society to accept diversity despite some disagreements over several ethnic-based issues. The state has setup a strong foundation for each race to enjoy social mobility and growth, thus living in harmony is preferred by the races.
\end{abstract}

iii For further information, refer to the complete PEI-3 data set, a YouTube video presentation and a copy of the Year in Elections 2014 report by Pippa Norris, Ferran Martinez Coma and Max Groemping can be downloaded from www.electoralintegrityproject.com or see https://www.washingtonpost.com/blogs/monkeycage/wp/2015/02/16/the-best-and-worst-elections-of-2014/

\begin{abstract}
${ }^{\text {iv }}$ A state without nation is a term used to explain that Malaysia is a sovereign state but the vernacular identities of multiethnic society remain pivotal. As a result a common national identity accepted by the society is yet to be created. In addition, the issue of the nation was never resolved because of the different communities and sub communities have their own vision and mission of the Malaysia they want to be. Each of this notion of nation is referred to nation of intent. See Shamsul AB. 2008. Many Ethnicities, Many Cultures, One Nation: The Malaysian Experience. UKM Ethnic Studies Paper Series, No. 2 (November): Institute of Ethnic Studies KITA: Selangor.
\end{abstract}

\begin{abstract}
${ }^{v}$ The fourteen general election showed the defeat of $\mathrm{BN}$ after more than 40 years in power. BN was established in 1974 but its predecessors the Alliance was established in 1959 to face the first General Election in Malaya after independence. The common reasons cited for the defeat of $\mathrm{BN}$ are the scandal and corruption pertaining to $1 \mathrm{MDB}$ (the misuse of state funds); the introduction of GST tax that outraged the public; high cost of living; the introduction of Anti Fake News Act of 2018; and also the Mahathir's comeback that swayed the majority Malays voters to vote for Pakatan Harapan, see https://www.thestar.com.my/news/nation/2018/05/10/analystson-bn-loss/
\end{abstract}

